\title{
Vector Analysis of Electrical Networks for Temperature Measurement of MOS Power Transistors
}

Błażej Torzyk, Bogusław Więcek

Lodz University of Technology, Institute of Electronics, Al. Politechniki 10, B-9 building, 93-590 Lodz, Poland

\begin{abstract}
The article presents the concept of using VNA (Vector Network Analyzer) to measure the temperature of the MOS transistor junction. The method assumes that the scattering parameters of the network consisting of the transistor depend on the temperature. The tests confirmed the influence of temperature on the $S_{11}$ parameter and the input network capacity during ambient temperature changes in the range of $35-70^{\circ} \mathrm{C}$. Measurements were made for the gate-source (G-S) input of the system. The measurements were carried-out with the transistor in the ON/OFF states. In order to validate the measurements, the temperature of the tested element was recorded with the MWIR Cedip-Titanium thermal imaging camera.
\end{abstract}

Keywords: Vector Network Analyzer, IR camera measurement, S-parameter, MOS transistor, electrical impedance

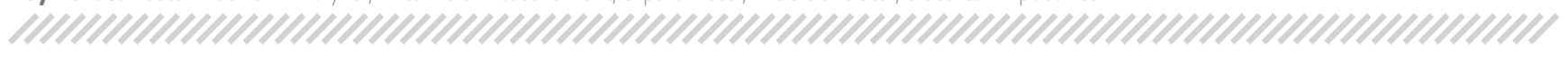

\section{Introduction}

Measurement of the internal temperature of semiconductor power devices is normally performed with an additional temperature sensor integrated with DUT (Device Under Test). In the case of bipolar transistors (BJT), the base-emitter diode can be used to measure the temperature. Power MOS transistors have a parasitic p-n technological diode, which can be used as a temperature sensor $[2,3]$ when the transistor is turned off. Such a measurement requires the application of a low-value current source connected in an appropriate state of operation of a transistor [4].

For MOS transistors, the ON-state resistance $\mathrm{R}_{\text {on }}$ of the channel varies with temperature and current [1]. There were attempts to use $\mathrm{R}_{\text {on }}$ resistance to measure the internal temperature of DUT. Most of the proposed measurement methods are off-line ones, recommended for manufacturers of semiconductor devices for the verification of production quality or for system developers for the selection of appropriate components. There is a commercially available system for monitoring the internal temperature of semiconductor elements, based either on an integrated p-n junction or on an external temperature sensor to measure temperature [12].

\section{Autor korespondujący:}

Błażej Torzyk, blazej.torzyk@p.lodz.pl

\section{Artykuł recenzowany}

nadesłany 08.08.2021 r., przyjęty do druku 14.10.2021 r.
In the field of high frequency and microwave electronic circuits, the vector analysis approach is very useful. Until now, such systems were intended rather for laboratory applications [5]. Currently, there are portable and handy Vector Network Analysers with acceptable technical specifications for various applications $[6,7]$. Such measurement systems power the DUT and measure the electrical response over the wide frequency range, sometimes up to GHz. The results can be presented in the form of frequency dependent electrical impedance/admittance, but in most cases they provide scattering (S) parameters very useful in the development of microwave and antenna circuits [8-10].

There is a need to measure the temperature of the semiconductor structure of power devices that do not have any $\mathrm{p}-\mathrm{n}$ junction inside, e.g. GaN transistors. This research is devoted to such applications and can be applied to AC and DC converters equipped with such modern elements. The main research hypothesis presented in the article is the possible use of the VNA and scattering parameters $\mathrm{S}$ to monitor the temperature inside power semiconductor devices.

The power MOS transistor contains parasitic capacitances between all electrodes (Fig. 1). These capacitors correspond to the input, output and feedback capacitances $\left(C_{i s s}, C_{o s s}, C_{r s s}\right)$ measured by the manufacturers and reported in application notes [13].

The dependence between to the input, output and feedback capacitances $C_{i s s}, C_{o s s}, C_{r s s}$ and the physically existing ones $C_{g s}, C_{g d}, C_{d s}$, can be expressed by eq. (1) and (2) [11].

$$
\begin{gathered}
C_{i s s}=C_{g s}+C_{g d} \\
C_{r s s}=C_{g d}
\end{gathered}
$$

$C_{o s s}=C_{d s}+\frac{C_{g d} C_{g s}}{C_{g d}+C_{g s}} \quad C_{d s}=C_{o s s}-\frac{C_{r s s}\left(C_{i s s}-C_{r s s}\right)}{C_{i s s}}$ 
D

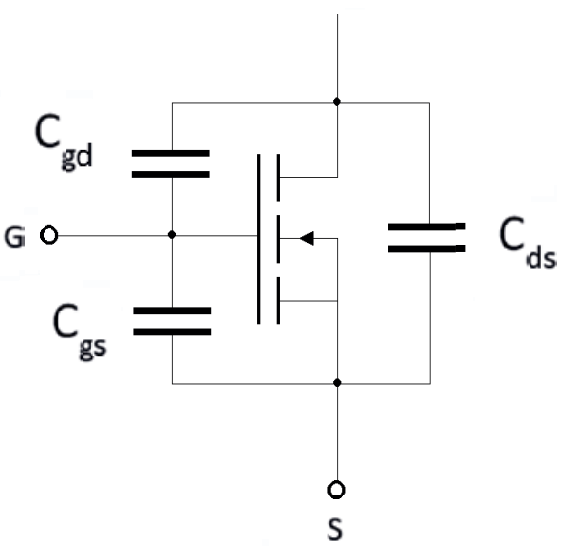

Fig. 1. Parasitic capacitances of MOS transistor Rys. 1. Pojemności pasożytnicze tranzystora MOS

The developed method and the results obtained confirm the validity of the concept of a new approach to measure the temperature of electronic devices with the use of VNA. However, the authors treat them as preliminary results that should be carefully analysed during the further research.

\section{Measurement setup}

For the research presented in this paper, the n-channel enhancement mode IRFZ44N Trench MOS transistor was selected. For this transistor, input capacitance $C_{i s s}=1350-1800 \mathrm{pF}$, output capacitance $C_{\text {oss }}=330-400 \mathrm{pF}$ and feedback capacitance $C_{r s s}=155-215 \mathrm{pF}$, measured for $V_{G S}=0 \mathrm{~V}, V_{D S}=25 \mathrm{~V}$ and for $f=1 \mathrm{MHz}$. The similar electrical conditions were selected for the measurements during this research.

In order to verify the influence of ambient temperature changes on the tested MOS transistor IRFZ44N in the TO220AB housing, a BINDER ED 115 heating chamber was used. The DUT device was affected by natural convection anly. The temperature range of the chamber is $\mathrm{T}_{\text {HEAT }}$ from $5{ }^{\circ} \mathrm{C}$ above ambient temperature to $300{ }^{\circ} \mathrm{C}$. The inspection opening made by the manufacturer in the upper part of the heating chamber allowed for recording the $\mathrm{S}_{11}$ parameters using portable VNA. A portable, inexpensive VNA was used for measurements. The device has a frequency range of $50 \mathrm{kHz}-1500 \mathrm{MHz}$ and the maximum output power of $-9 \mathrm{dBm}$.

At the same time, temperature changes on the tested transistor were monitored with the Cedip-Titanium MWIR (Medium Wave Infrared Range) camera through the another inspection opening in the side wall of the heating chamber. The IR camera is characterized by high recording speed up to 1000 frames per second. The thermal resolution of the camera is NETD $<18 \mathrm{mK}$, and the cooled InSb matrix contained $640 \times 512$ pixels. The signals recorded by the VNA and IR cameras were saved in the computer memory for the detailed analysis (Fig. 2).

The measurement was based on heating the chamber in the range of $35-70{ }^{\circ} \mathrm{C}$. The $\mathrm{S}_{11}$ parameter value changes were registered using a portable VNA every $5{ }^{\circ} \mathrm{C}$ of $\mathrm{T}_{\text {HEAT }}$ in the steady. The signal generated by the internal Si5351 oscillator built into the VNA was connected to the gate-source (G-S) pins of the tested MOS transistor (Fig. 2). The frequency range of the signal recorded by the VNA was $50 \mathrm{kHz}-20 \mathrm{MHz}$. Measurement data was collected with the software installed on the notebook. At the same time, the $\mathrm{T}_{\mathrm{MOS}}$ temperature was recorded by the IR camera with a sampling frequency of $100 \mathrm{~Hz}$ (Fig. 3). Additionally, measurements were made for either ON or OFF state of the tested device. The electrical conditions for these measurements were: $\mathrm{V}_{\mathrm{GS}}=0 \mathrm{~V}(\mathrm{OFF}) / 10 \mathrm{~V}(\mathrm{ON})$ and $\mathrm{V}_{\mathrm{DS}}=20 \mathrm{~V}$. The collected data was analyzed in order to estimate changes in the values of selected parameters as the function of the ambient temperature $\mathrm{T}_{\text {HEAT }}$ and $\mathrm{T}_{\text {MOS }}$.

Before the measurements, a simple simulation of the transistor's operation was carried out at the ambient temperature $\mathrm{T}_{\mathrm{a}}=25^{\circ} \mathrm{C}$ using the LTspice XVII program. The schematic diagram of the modeled circuit is shown in Fig. 4. In order to make the model compatible with the experiment, the series inductance $\mathrm{L}_{1}$ was added to the gate connection (Fig. 4). It corresponds to the inductance of the wire several $\mathrm{cm}$ long used in the experiment. Switching the transistor was achieved by changing the value of the resistance $R_{1}$ from a few $M \Omega$ to $10 \mathrm{k} \Omega$.

Voltage source $\mathrm{V}_{2}$ simulates the VNA generator. Changing the frequency of this generator allows to estimate the impedance character of the measured device. Due to the LC series branch, at lower frequency values the impedance between gate and ground starts from capacitive to resonance at frequency around $10 \mathrm{MHz}$. For higher frequencies, the input circuit becomes inductive. This simulation result is in line with the experimental result obtained by the VNA.

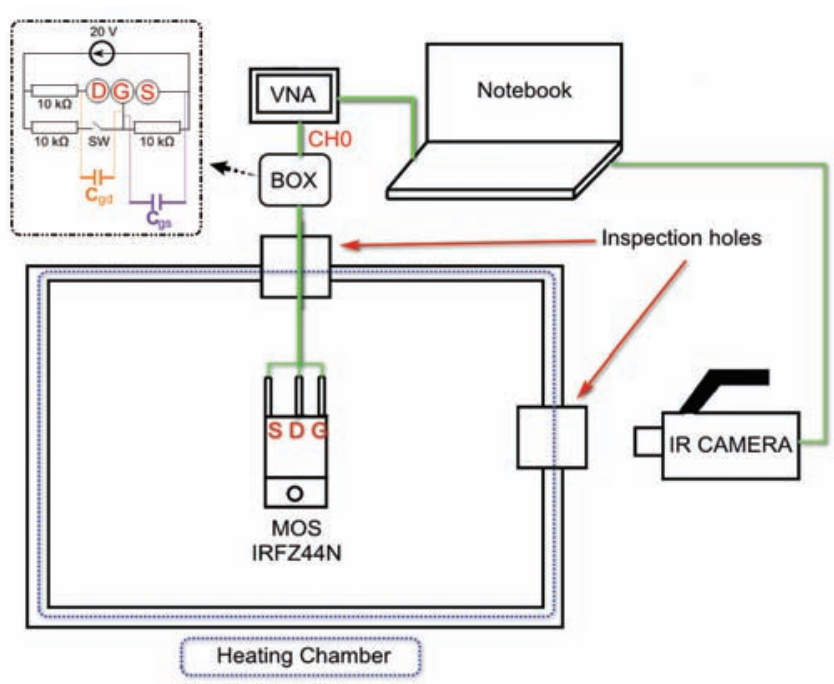

Fig. 2. Schematic diagram of the measurement setup

Rys. 2. Schemat ideowy stanowiska pomiarowego

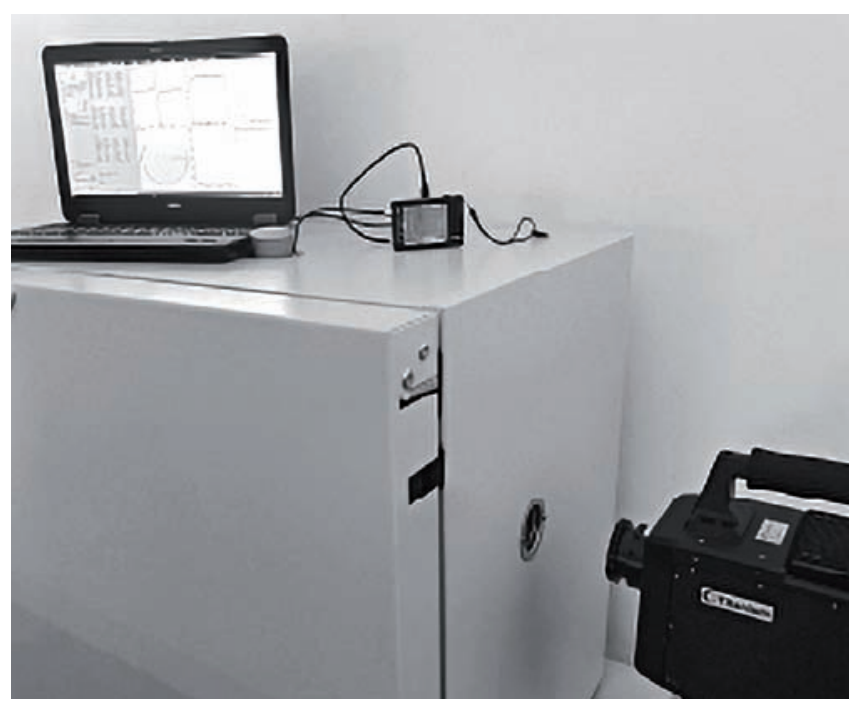

Fig. 3. Measurement setup with the heating chamber, VNA and IR camera

Rys. 3. Stanowisko pomiarowe: komora grzewcza, VNA oraz kamera IR 


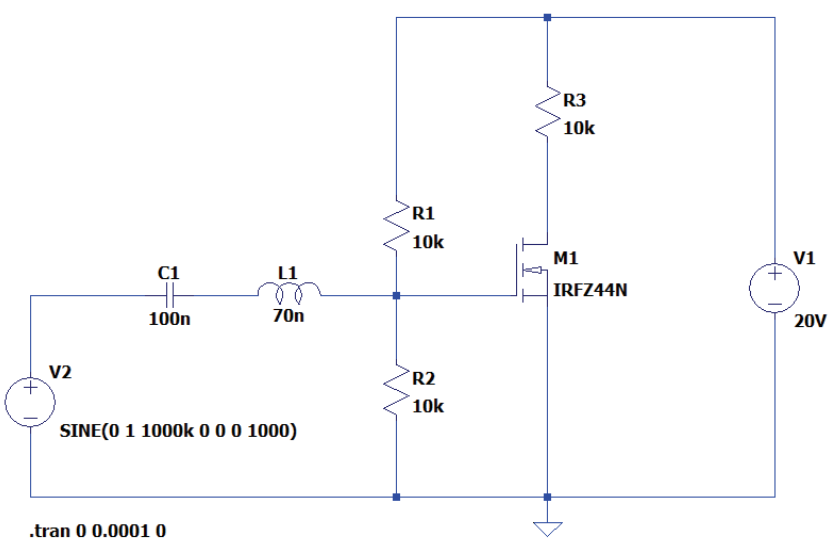

Fig. 4. The schematic diagram of the simulated circuit

Rys. 4. Schemat elektryczny symulowanego obwodu

\section{Experimental results}

Figure 5 shows the measured Smith chart representing the changes of $\mathrm{S}_{11}$ parameter value. The measurement of the selected parameters were performed for the frequency corresponding to $-\pi / 2$ phase shift of $S_{11}$ parameter. Experimentally, two values of excitation frequency were selected $f_{1}=1.0475 \mathrm{MHz}$ and $f_{2}=0.848 \mathrm{MHz}$ for which the phase shift is close $\phi \approx-\pi / 2$, indicated in Fig. 5 . According to the concept of new application of VNA and theoretical considerations, the input capacitance were analyzed. The circular shape of $\mathrm{S}_{11}$ in the Smith diagram confirms the almost pure capacitive character of the input circuit measured between the gate and the source electrode of the MOS transistor. Due to the series inductance, the character of the circuit changes to inductive above the frequency $f>10 \mathrm{MHz}$.

The sensitivity of the measured parameters is high, which results from the characteristic of the phase shift (Fig. 6). A significant and steep slope of the characteristic is for $\phi \approx-\pi / 2$. Negative phase shift values are related to the capacitive character of the internal in-build transistor structure. For this measurement condition, the high thermal sensitivity is expected. The obtained values of input capacitance $\mathrm{C}_{\text {in }}$ for both considered frequencies were averaged and the relation $\mathrm{C}_{\text {in }}=f\left(\mathrm{~T}_{\mathrm{MOS}}\right)$

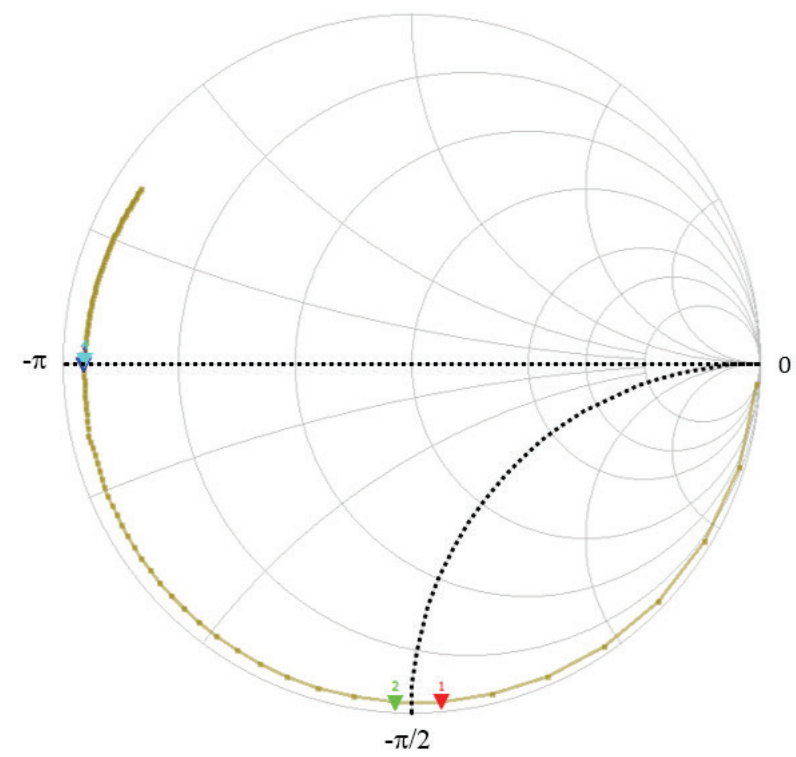

Fig. 5. Example of the $S_{11}$ parameter changes for frequency range $f \in(0.05,20) \mathrm{MHz}$

Rys. 5. Przykład zmian parametru $\mathrm{S}_{11}$ w zakresie częstotliwości $f \in(0.05,20) \mathrm{MHz}$ was determined for ON and OFF states of DUT. The obtained numerical results of the measurements are presented in Table 1. The temperature in the heating chamber can only be set above the ambient temperature. Therefore, a starting temperature of $35{ }^{\circ} \mathrm{C}$ was selected.

The measurement system was developed to reduce or nearly eliminate self-heating of a transistor (Figures 2 and 4). This is due to the small value of the drain current of several $\mathrm{mA}$. Analyzing the data presented in Tables 1, it can be seen that the ambient temperature $\mathrm{T}_{\text {HEAT }}$ set by the heating chamber corresponds linearly to the temperature $\mathrm{T}_{\mathrm{MOS}}$ measured by a thermal imaging camera. However, there is a difference between the $\mathrm{T}_{\mathrm{EAT}}$ and $\mathrm{T}_{\mathrm{MOS}}$ temperatures due to the nonhomogeneous temperature distribution and the long settling time in the heating chamber. Nevertheless, the $\mathrm{T}_{\text {MOS }}$ takes almost the same value for both measurements, regardless of the transistor state ON/OFF. This is confirmed by the lack of self-heating effect of the transistor in the ON state.

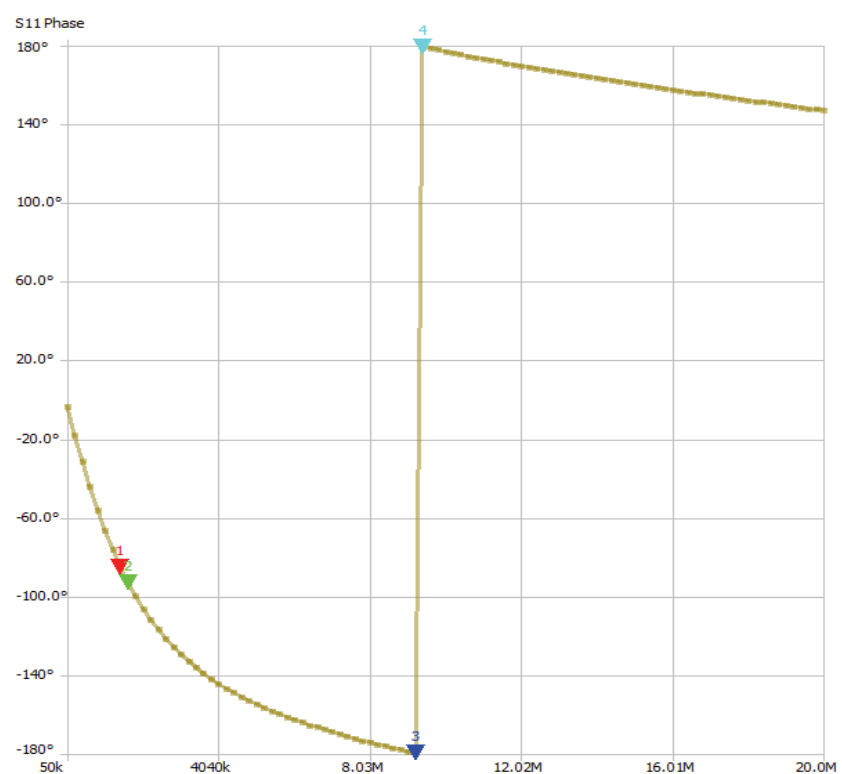

Fig. 6. Example of the phase change characteristic of $S_{11}$ parameter $\left(1^{\text {st }}\right.$ and $2^{\text {nd }}$ marker $-\phi \approx-\pi / 2$; 3rd marker $\phi \approx-\pi$, 4th marker $\phi \approx \pi$ ) Rys. 6. Przykładowa charakterystyka zmiany przesunięcia fazowego parametru $\mathrm{S}_{11}(1,2$ marker $-\phi \approx-\pi / 2 ; 3$ marker $\phi \approx-\pi, 4$ marker $\phi \approx \pi)$

Table 1. Summary of changes in the series capacitance Cin versus temperature $T_{\text {MOS }}$ and $T_{\text {HEAT }}$ for ON and OFF states of DUT Tabela 1. Zestawienie zmian pojemności Cin względem temperatur $T_{\text {MOs }}$ oraz $\mathrm{T}_{\text {HEAT }}$ dla stanu pracy ON/OFF

\begin{tabular}{|c|c|c|c|c|}
\hline \multirow{2}{*}{$\mathrm{T}_{\text {HEAT }}\left({ }^{\circ} \mathrm{C}\right)$} & \multicolumn{2}{|c|}{$\mathrm{GS}_{\text {OFF }}$} & \multicolumn{2}{c|}{$\mathrm{GS}_{\text {ON }}$} \\
\cline { 2 - 5 } & $\mathrm{T}_{\text {MOS }}\left({ }^{\circ} \mathrm{C}\right)$ & $\mathrm{C}_{\text {in }}(\mathrm{nF})$ & $\mathrm{T}_{\text {MOS }}\left({ }^{\circ} \mathrm{C}\right)$ & $\mathrm{C}_{\text {in }}(\mathrm{nF})$ \\
\hline 35.00 & 33.67 & 3.11610 & 33.81 & 3.15025 \\
\hline 40.00 & 41.06 & 3.11305 & 40.45 & 3.14640 \\
\hline 45.00 & 47.59 & 3.11045 & 47.43 & 3.14350 \\
\hline 50.00 & 54.37 & 3.10895 & 53.40 & 3.14100 \\
\hline 55.00 & 61.43 & 3.10620 & 60.74 & 3.13865 \\
\hline 60.00 & 66.56 & 3.10470 & 66.89 & 3.13645 \\
\hline 65.00 & 71.13 & 3.10340 & 71.73 & 3.13500 \\
\hline 70.00 & 76.10 & 3.10150 & 76.11 & 3.13205 \\
\hline
\end{tabular}



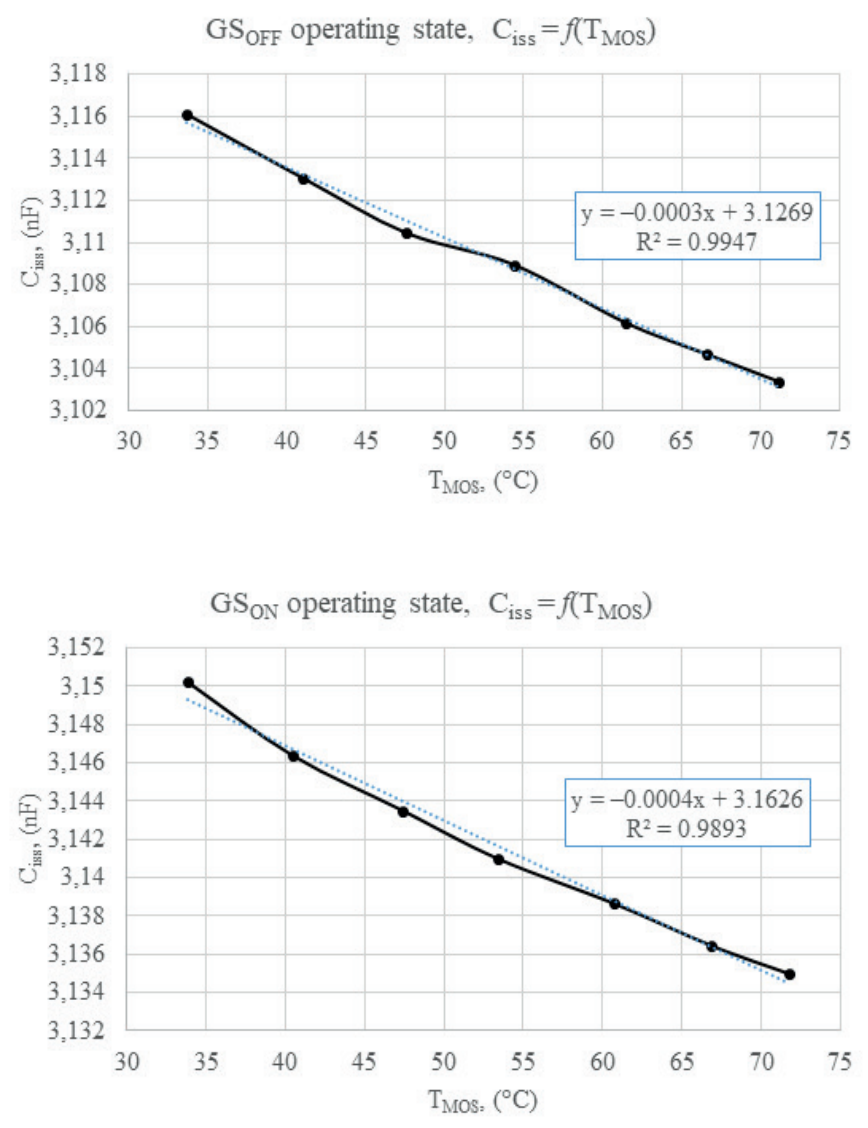

Fig. 7. Dependence of $C_{\text {iss }}$ capacitance as a function $C_{\text {iss }}=f\left(T_{\text {MOS }}\right)$, for ON and OFF state of N-channel enhancement mode IRFZ44N TrenchMOS transistor

Rys. 7. Zależność pojemności $\mathrm{C}_{\text {iss }}$ w funkcji $\mathrm{C}_{\text {iss }}=f\left(\mathrm{~T}_{\text {Mos }}\right)$ dla tranzystora, $\mathrm{w}$ stanie pracy ON/OFF - IRFZ44N TrenchMOS z kanałem typu $n$

These changes of $\mathrm{T}_{\text {MOS }}$ temperature varies the series capacitance for both measurements setup (ON/OFF).

The values of the input capacitance in both states are very similar. For the ON state of the input capacitance of the transistor it is slightly larger due to the bypassing of the drain capacitance. The input capacitance decreases with temperature as shown in Fig. 7.

The input capacitance depends on the ambient temperature and the operating state of the transistor. After averaging the value of the input capacitance for 2 adjacent frequencies near the phase of $S_{11}$ equal to $-\pi / 2$, the input capacitance changes by $-16.4 \mathrm{pF}$ with increasing temperature $\mathrm{T}_{\mathrm{MOS}}$ from $33.67^{\circ} \mathrm{C}$ to $76.10^{\circ} \mathrm{C}$.

The nearly linear characteristics of capacitance change as a function of temperature $\mathrm{T}_{\mathrm{MOS}}$ exhibit the sensitivity of capacitance variation versus temperature as in eq. (3).

$$
\frac{\partial C_{i n}}{\partial T_{M O S}}=-0.39 \frac{\mathrm{pF}}{{ }^{\circ} \mathrm{C}}
$$

\section{Conclusions}

The use of the VNA as a measuring device for $\mathrm{S}_{11}$ parameter allows the determination the impedance character of the electrical network consisting of a MOS transistor. Electrical parameters were measured for the appropriate frequency. As the temperature of the transistor increases, the input capacitance decreases.
The temperature $\mathrm{T}_{\text {Mos }}$ ranged from $33.67{ }^{\circ} \mathrm{C}$ to $76.10^{\circ} \mathrm{C}$. The temperature set by the control system of the heating chamber $\mathrm{T}_{\text {HEAT }}$ was slightly higher. An increase in $\mathrm{T}_{\text {MOS }}$ temperature by approximately $40{ }^{\circ} \mathrm{C}$ caused a capacity decrease by approximately $16 \mathrm{pF}$. This means that the average sensitivity of capacitance changes as a function of temperature is $-0.39 \mathrm{pF}$ per $1{ }^{\circ} \mathrm{C}$ for the temperature $\mathrm{T}_{\text {MOS }}$ measured with the IR camera.

The obtained results of these preliminary studies confirmed the correctness of the new approach to monitor static and dynamic temperature changes inside the structure of MOS transistors with the use of $\mathrm{S}_{11}$ parameter. The application of the VNA to measure temperature changes requires calibration for each test object to determine the frequency for phase of $\mathrm{S}_{11}$ equal to $\phi \approx-\pi / 2$. Presumably, adjusting an appropriately narrow frequency range for analysis will increase the accuracy of the measurement and eliminate the fluctuations of capacitance changes visible in the obtained results (Fig. 7).

The obtained results are too early to provide clear evidence and exact dependencies for the new measurement method of junction temperature of MOS transistors. The research requires further works and the development of a dedicated measuring system in order to increase the precision and sensitivity of the registered changes in series capacitance and the temperature of the transistor's internal structures. In particular, an uncertainty analysis will be performed to confirm the practical suitability of the proposed method. However, preliminary research and the results presented are promising.

\section{References}

1. Williams R.K., Darwish M.N., Blanchard R.A., Siemieniec R., Rutter P., Kawaguch Y., The trench power MOSFET: Part I - History, technology, and prospects, "IEEE Transactions on Electron Devices", Vol. 64, No. 3, 2017, 674-691, DOI: $10.1109 /$ TED.2017.2653239.

2. Pangallo G., Rao S., Adinolfi G., Graditi G., Della Corte F.G., Power MOSFET Intrinsic Diode as a Highly Linear Junction Temperature Sensor, "IEEE Sensor Journal", Vol. 19, No. 23, 2019, 11034-11040,

DOI: 10.1109/JSEN.2019.2935550.

3. Blackburn D., Berning D., Power MOSFET temperature measurements, Proceedings of IEEE Power Electronic Specialists Conference, 1982, 400-407,

DOI: 10.1109/PESC.1982.7072436.

4. Wenger Y., Meinerzhagen B., Low-Voltage Current and Voltage Reference Design Based on the MOSFET ZTC Effect, "IEEE Transactions on Circuits and Systems", Vol. 66, No. 9, 2019, 3445-3456, DOI: 10.1109/TCSI.2019.2925266.

5. Niu H., Lorenz R.D., Sensing Power MOSFET Junction Temperature Using Gate Drive Turn-On Current Transient Properties. November 2015, "IEEE Transactions on Industry Applications", Vol. 52, No. 2, 2015, 1677-1687,

DOI: 10.1109/TIA.2015.2497202.

6. Bonaguide G., Jarvis N., The VNA Applications Handbook, Artech House 2019.

7. Dunsmore J.P., Handbook of Microwave Component Measurement: with Advanced VNA Techniques, $2^{\text {nd }}$ Edition, Wiley, May 2020.

8. Heddallikar A., Pinto R., Prasadh S.S., A Comparative Analysis of Dielectric Fill Material for X Band Antenna and Subsystem using Scattering Parameters, 2018 IEEE MTT-S International Microwave and RF Conference (IMaRC), October 2019, DOI: 10.1109/IMaRC.2018.8877254.

9. Zhipeng Wu, Software VNA and Microwave Network Design and Characterisation, Wiley, September 2007. 
10. Berthou M., Godignom P., Millan J., Monolithically Integrated Temperature Sensor in Silicon Carbide Power MOSFETs, IEEE Transactions on Power Electronics, Vol. 29, No. 9, 2014, 4970-4977, DOI: 10.1109/TPEL.2013.2289013.

11. Zwerver H.J., LTspice built in VDMOS model, 04 Dec 2006, http://www.magma.ca/ legg/SR5/LTspice_built_in_ VDMOS_model.pdf.
12. Szekely V., Ress S., Poppe A., Török S., Magyari D., Benedek Z., Torki K., Courtois B., Rencz M., New approaches in the transient thermal measurements. "Microelectronics Journal", Elsevier, Vol. 31, No. 9-10, October, 2000, 727-733, DOI: 10.1016/S0026-2692(00)00051-3.

13. Application Note, July 2018, https://toshiba.semicon-storage.com/info/docget.jsp?did=13415.

\section{Zastosowanie analizy wektorowej sieci elektrycznych do pomiaru temperatury tranzystorów MOS}

Streszczenie: W artykule przedstawiono koncepcję wykorzystania wektorowego analizatora sieci VNA (ang. Vector Network Analyzer) do pomiaru temperatury złącza tranzystora MOS. Metoda zakłada, że parametry rozpraszania sieci elektrycznych wewnętrznych struktur tranzystora zależą od temperatury. Badania potwierdziły wpływ temperatury na parametr $\mathrm{S}_{11}$ oraz na pojemność wejściową przy zmianie wartości temperatury otoczenia w zakresie $35-70^{\circ} \mathrm{C}$. Pomiary wykonano dla wejścia bramka-źródło (G-S) układu. Pomiary przeprowadzono z tranzystorem w stanach ON/OFF. W celu walidacji pomiarów, temperaturę badanego elementu rejestrowano kamerą termowizyjną MWIR Cedip-Titanium.

Słowa kluczowe: VNA, Wektorowy Analizator Sieci, temperatura, parametry rozpraszania, parametry S, tranzystor MOS, impedancja elektryczna, pomiary termowizyjne

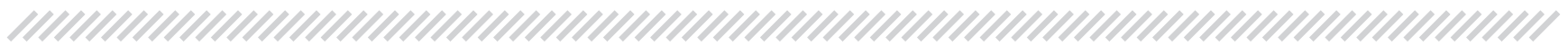

\section{Prof. Bogusław Więcek, PhD DSc}

boguslaw.wiecek@p.lodz.p ORCID: 0000-0002-5003-1687

Bogusław Więcek is the head of Electronic Circuit and Thermography Division in the Institute of Electronics where he has been working for more than 40 years. His scientific interests are: heat transfer modelling, industrial and biomedical applications of IR thermography and IR system modelling and developments. He is responsible

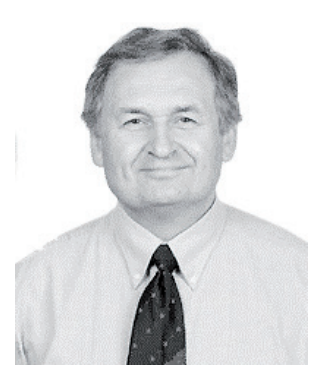
for organizing the largest conference on thermography in Central and Easter Europe every two years "Infrared thermography and thermometry - TTP".

\section{Błażej Torzyk, MSc}

blazej.torzyk@p.lodz.pl ORCID: 0000-0003-4387-2741

He received BSc degree in Electronics and Telecommunication at Technical University of Lodz in 2013 and the MSc degree in Electrical Engineering, specialization Electric Power Engineering in 2015. Currently he is a PhD student at the Electronic Circuits and Thermography Department of Lodz University of Technology. His research interests lie in the fields IR thermography at power electronics sys tems and devices. 